\title{
Effect of Vermicomposted Vegetable and Fruit Wastes on the Vegetative and Yield Parameters of Lablab [Lablab Purpureus (L.) Sweet]
}

Pinky Raihing, A. Vijayalakshmi

10.18805/ag.D-5476

\begin{abstract}
Background: Organic farming are degradation of organic materials and less use of chemical fertilizers and pesticides. Vermicomposting is the process of introducing earthworm species into the compost. It behaves as eco-friendly manure and gives good health to soil. Methods: The present study was conducted at Avinashilingam Institute for Home Science and Higher Education for Women, Coimbatore over a period of 3 months from March to May 2019. There are 8 treatments namely $T_{1}-T_{8}$ and control. The effect of incorporation of vegetable and fruit wastes biocompost on the vegetative parameters such as shoot length, root length, number of leaves, fresh weight and dry weight on 15, 35, 55 DAS and yield characters i.e. number of pods/plants, number of seeds/pods, pod length, weight of the seed, pod fresh weight and dry weight on 75 DAS in Lablab [Lablab purpureus (L.) Sweet] were analysed.

Result: The results from study revealed that $T_{8}$ treatment showed significant increase in shoot length $(113.7,124.5$ and $135 \mathrm{~cm})$, root length (13.2, 18.5 and $27 \mathrm{~cm})$, number of leaves (22, 39 and 48), fresh weight $(4.911,15.693$ and $21.244 \mathrm{~g})$ and dry weight $(0.652$, 2.156 and $3.234 \mathrm{~g}$ ) on 15, 35, 55 DAS and yield parameters such as number of pods/plants (40), number of seeds/pods (6), pod length $(13 \mathrm{~cm})$, weight of the seed $(4.060 \mathrm{~g})$, pod fresh weight $(7.425 \mathrm{~g})$ and dry weight $(1.382 \mathrm{~g})$ on 75 DAS in Lablab over control. The study concluded that $\mathrm{T}_{8}$ treatment is an effective manure which can be used to enhance plant growth, provide better yield which will be beneficial for farmers.
\end{abstract}

Key word: Lablab purpureus (L.) Sweet, Root length, Shoot length, Vegetable and fruit wastes.

\section{INTRODUCTION}

Next to china, India is the largest producer of fruits and vegetables in the world. About $18 \%$ of the output is wasted every year. In Tamil Nadu, $61 \%$ of the fruits and vegetables are wasted due to lack of proper storage facilities in the state. Organic farming is the degradation of organic matter to produce eco-friendly compost or manure. Organic farming is important since it does not use chemical fertilizers and pesticides in farming. Municipal solid waste is easily available and very useful for soil fertility. Organic waste and the biofertilizers are the alternate sources that meet the nutrient requirement on crops. India produces about 3000 million tons of organic waste which can be degraded and produce eco-friendly manure for sustainable environment (Achsah and Prabha, 2013). Vermicomposting is a cheap low-cost biotechnological process of composting where species of earthworm is introduced to produce a better end product. Vermicompost application promoted the plant growth and also protects the crops from the pest and diseases (Sinha et al., 2010). Chemical fertilizer may apply to increase the yield of the crop for a short duration but it will also affect the soil fertility, soil degradation and deteriorate the environment. Nutrient content of the vermicompost is much higher. Earthworms are responsible for breaking down of complex substances in the organic waste into simple water-soluble substances (Datar et al., 1997). Vermicomposting is in the same line with the principle of
Department of Botany, Avinashilingam Institute for Home Science and Higher Education for Women, Coimbatore-641 043, Tamil Nadu, India.

Corresponding Author: Pinky Raihing, Department of Botany, Avinashilingam Institute for Home Science and Higher Education for Women, Coimbatore-641 043, Tamil Nadu, India.

Email: raihingpinky17@gmail.com

How to cite this article: Raihing, P. and Vijayalakshmi, A. (2021). Effect of Vermicomposted Vegetable and Fruit Wastes on the Vegetative and Yield Parameters of Lablab [Lablab Purpureus (L.) Sweet]. Agricultural Science Digest. DOI: 10.18805/ag.D-5476.

Submitted: 20-08-2021 Accepted: 09-10-2021 Online: 03-11-2021

healthy environment because it has the value of resource conservation and sustainable practices, as a process for handling organic residue which is an alternative approach in waste management, which is not dumped or incinerated but recycled (Aalok et al., 2008). Vermicompost improves soil structure, soil moisture holding capacity, vegetative growth and enhance crop yield. Lablab [Lablab purpureus (L.) Sweet], Var. Co. (Gb) 14 is a bushy, or climbing and branching, herbaceous, annual plant. It is commonly known as hyacinth bean and belongs to a family Fabaceae. Lablab is an ancient crop and has been documented by the archaeobotanical finder in India before 1500 BC (Fuller, 2003). Lablab is the third most important vegetables in the 
Effect of Vermicomposted Vegetable and Fruit Wastes on the Vegetative and Yield Parameters of Lablab [Lablab Purpureus (L.)...

central and western part of Bangladesh after eggplant (Solanum melongena) and taro (Colocasia spp.) and is reported to have a total production area of approximately 48,000 ha (Rashid et al., 2006). It produces a twining stem that can be 6 - 9 meters long. The plant is best known for its edible seed. The present study is carried out to analyse the effect of vegetable and fruit wastes as manure on the biometric characters such as root length, shoot length, number of leaves, fresh weight and dry weight in leaves and yield parameters in seeds of Lablab.

\section{MATERIALS AND METHODS}

Composting is the biodegradation of organic matter to produce a better manure. Vermicomposting is the introduction of earthworm species into the compost and incorporated into the soil to increase the yield of plant. Vermicomposting was carried out during winter season (November-January). The pot culture study was conducted during March to May 2019 at Avinashilingam Institute for Home Science and Higher Education for Women, Coimbatore, Tamil Nadu.

\section{Collection of waste}

The vegetable waste is collected from in and around Saibaba Colony, Coimbatore, Tamil Nadu. The fruits waste is collected from outside and inside the campus fruit stall of Avinashilingam Institute for Home Science and Higher Education for Women, Coimbatore $\left(11.0196^{\circ} \mathrm{N}, 76.9504^{\circ} \mathrm{E}\right)$ in large quantity. It is cut into small pieces, sun dried and stored in polythene bag.

\section{Collection of seed}

The seeds of Lablab [Lablab purpureus (L.) Sweet] were obtained from Tamil Nadu Agriculture University, Coimbatore, Tamil Nadu. Seeds were selected for pot culture studies with three replications in each treatment.

\section{The experimental treatment}

A pot culture experiment, filled with $7 \mathrm{~kg}$ of sandy loam clay soil was carried out. Around 10 seeds were sown and 5 healthy plants were maintained in pot for the study. Three replications were maintained. The treatments given were C - Control

$\mathrm{T}_{1}$ - Vegetable Wastes + cow dung + Eudrilus eugeniae (5 t ha).

$\mathrm{T}_{2}$ - Vegetable Wastes + cow dung + Pleurotus eous + Eudrilus eugeniae (5 t/ha).

$\mathrm{T}_{3}$ - Vegetable Wastes + cow dung + Trichoderma asperelloides + Eudrilus eugeniae (5 t/ha).

$\mathrm{T}_{4}-$ Vegetable Wastes + cow dung $+P$. eous $+T$. asperelloides + Eudrilus eugeniae (5 t/ha).

$\mathrm{T}_{5}$ - Fruit Wastes + cow dung + Eudrilus eugeniae (5 t/ha).

$\mathrm{T}_{6}$ - Fruit Wastes + cow dung + Pleurotus eous + Eudrilus eugeniae (5 t/ha).

$\mathrm{T}_{7}$ - Fruit Wastes + cow dung + Trichoderma asperelloides + Eudrilus eugeniae (5 t/ha).

$\mathrm{T}_{8}$ - Fruit Wastes + cow dung $+P$. eous $+T$. asperelloides + Eudrilus eugeniae (5 t/ha).

\section{Vegetative parameters}

The plant was uprooted on 15, 35 and 55 day after sowing (DAS) to evaluate its vegetative parameters such as root length, shoot length, number of leaves, fresh weight and dry weight in leaves of Lablab plant.

\section{Yield parameters}

The yield parameters such as number of pods/plants, number of seeds/pods, pod length, weight of the seed, pod fresh weight and dry weight were analyzed on 75 day after sowing (DAS).

\section{Statistical analysis}

The data collected on vegetative parameters in leaves on 15,35 and 55 day after sowing (DAS) and yield parameters in seeds on 75 day after sowing (DAS) were analysed using one way and two-way ANOVA.

\section{RESULTS AND DISCUSSION Vegetative parameters}

The results of the present study predicted the effect of composts by different treatments on vegetative parameters of Lablab [Lablab purpureus (L) Sweet]. The results as showed in Fig 1 and 2, a highest shoot length was observed in $T_{8}$ treatment $(113.7,124.5$ and $135 \mathrm{~cm})$ which is followed by $\mathrm{T}_{4}$ treatment $(86.8,98$ and $109 \mathrm{~cm})$ and control $(41.2$, 63.5 and $76.5 \mathrm{~cm}$ ) on 15, 35 and 55 day after sowing (DAS). A significant increase in root length was observed in $T_{8}$ treatment $(13.2,19.3$ and $27 \mathrm{~cm})$ when compared to $T_{4}$ treatment $(10,18.5$ and $23.5 \mathrm{~cm})$ and control $(5.7,6.3$ and $7 \mathrm{~cm}$ ) on 15, 35 and 55 Day After Sowing (DAS). Maximum number of leaves was observed in $T_{8}$ treatment $(22,39$ and 48) which is followed by $T_{4}$ treatment (21, 35 and 44) and control on 15, 35 and 55 day after sowing (DAS). The fresh weight of the plant was observed highest in $\mathrm{T}_{8}$ treatment $(4.911,15.693$ and $21.244 \mathrm{~g})$ which is followed by $\mathrm{T}_{4}$ treatment $(4.044,8.523$ and $13.048 \mathrm{~g})$ and control. Similar results were also observed in dry weight, significant increase in $\mathrm{T}_{8}$ treatment $(0.652,2.156$ and $3.234 \mathrm{~g})$ when compared to $\mathrm{T}_{4}(0.554,1.526$ and $2.309 \mathrm{~g})$ treatment and control $(0.124$, 0.260 and $0.375 \mathrm{~g}$ ) on 15,35 and 55 day after sowing (DAS).

The present investigation agrees with the previous work on Cyamopsis tetragonoloba where application of vermicompost increases the shoot length (Pavithra and Lakshmi Prabha, 2014). The result is in par with Joshi et al. (2016) who observed significantly higher plant height recorded at 60 DAS $(59.37 \mathrm{~cm})$ and at harvest $(62.00 \mathrm{~cm})$ of the crop with the application of treatment RDF (20-40-0 $\mathrm{kg} \mathrm{NPK} \mathrm{ha-1)}$ compared to treatment (Control).

The present study was also in agreement with the results in peanut where an increase in plant height (16.83) with the application of soil $+100 \%$ compost peanut shells was observed (Omidi et al., 2017). The maximum shoot length and root length was observed in treatments S4vermicompost of Phumdi (Dey et al., 2019). A significant increase in shoot length and root length was observed in $T_{4}$ 
treatment- Fruit Waste + cow dung + Pleurotus eous + Trichoderma asperelloides + Eudrilus eugeniae (5t/ha) when compared to Control (plain soil) on 15, 35 and 55 DAS in black gram (Pinky Raihing and Vijayalakshmi, 2020).

The previous study reported that maximum number of leaves was obtained 6.43 for pig compost, 7.25 for chicken compost, over control 6.23 (Coulibaly et al., 2019). The number of leaves recorded was far higher in Ecodrum compost treatment (13.66) amended pot media as against other treatments and control (8.66) in Chinese kale which also coincides the results of our study (Al-Sabbagh et al., 2020). Similar results were found in Nasar et al. (2019).

The experimental results were also on par with findings that the application of municipal waste compost (20 t/ha) significantly enhanced the fresh weight (shoots-195.2gm, roots-62.3gm) and dry weight (shoots-51.2gm, roots$13.5 \mathrm{gm}$ ) of tomato crop (Mehdizadeh et al., 2013) and the fresh weight and dry weight of radish which was maximum in $S_{M}$ (Soil Medium) (50\% of compost) $8.14 \mathrm{gm}, 0.78 \mathrm{gm}$ which is followed by $S_{H}$ (Soil High) (100\% of compost) 7.91 $\mathrm{gm}, 0.73 \mathrm{gm}$ and $S$ (control) $4.87 \mathrm{gm}$ and $0.41 \mathrm{gm}$ (Afriyie and Amoabeng, 2017).

\section{Yield parameters}

As shown in Table 1, maximum number of pods/plants was observed in $T_{8}$ (40) treatment, followed by $T_{4}$ (35) when compared to control (16). The pod length and number of seeds/pods are significantly increased in $T_{8}(13 \mathrm{~cm}$ and 6$)$ treatment followed by $T_{4}(12.30 \mathrm{~cm}$ and 5.20$)$ treatment. The fresh and dry weight content of the pods observed maximum in $T_{8}$ treatment $(7.425$ and $1.382 \mathrm{~g})$ which is followed by $T_{4}$ treatment $(7.003$ and $1.122 \mathrm{~g})$ and control (4.408 and 0.530 $\mathrm{g})$. The weight of the seed showed maximum in $\mathrm{T}_{8}(4.060 \mathrm{~g})$ followed by $\mathrm{T}_{4}(2.813 \mathrm{~g})$ treatment as compared to the other treatments and control $(1.771 \mathrm{~g})$ on 75 DAS.

A significant increase in number of pods per plant (11.33 to 16.67$)$, length of pod $(4.50 \mathrm{~cm}$ to $6.53 \mathrm{~cm})$, single pod weight $(0.23 \mathrm{gm}$ to $0.45 \mathrm{gm})$ and number of seeds per pod (8.00 to 10.00) with the application of Water Hyacinth- Green Manure $(200 \mathrm{mg})$ from 50 to 70 DAS over the control in green gram was observed (Padmaja and Jessy Paulose, 2011).

The present study coincides with the result of Yagoub et al., 2012 in Glycine max L. which showed an increase in number of pod / plants, number of seeds/pods in compost treatment.

The results is in par with Kumarimanimuthu and Kalaimathi (2020). The present results also coincide with the previous findings that integration of NPK (50\%) + FYM $(50 \%)+$ biofertilizers had significant positive impact on yield per plant $(1149 \mathrm{~g})$ and total yield $\left(11.05 \mathrm{t} \mathrm{ha}^{-1}\right)$ of king chilli
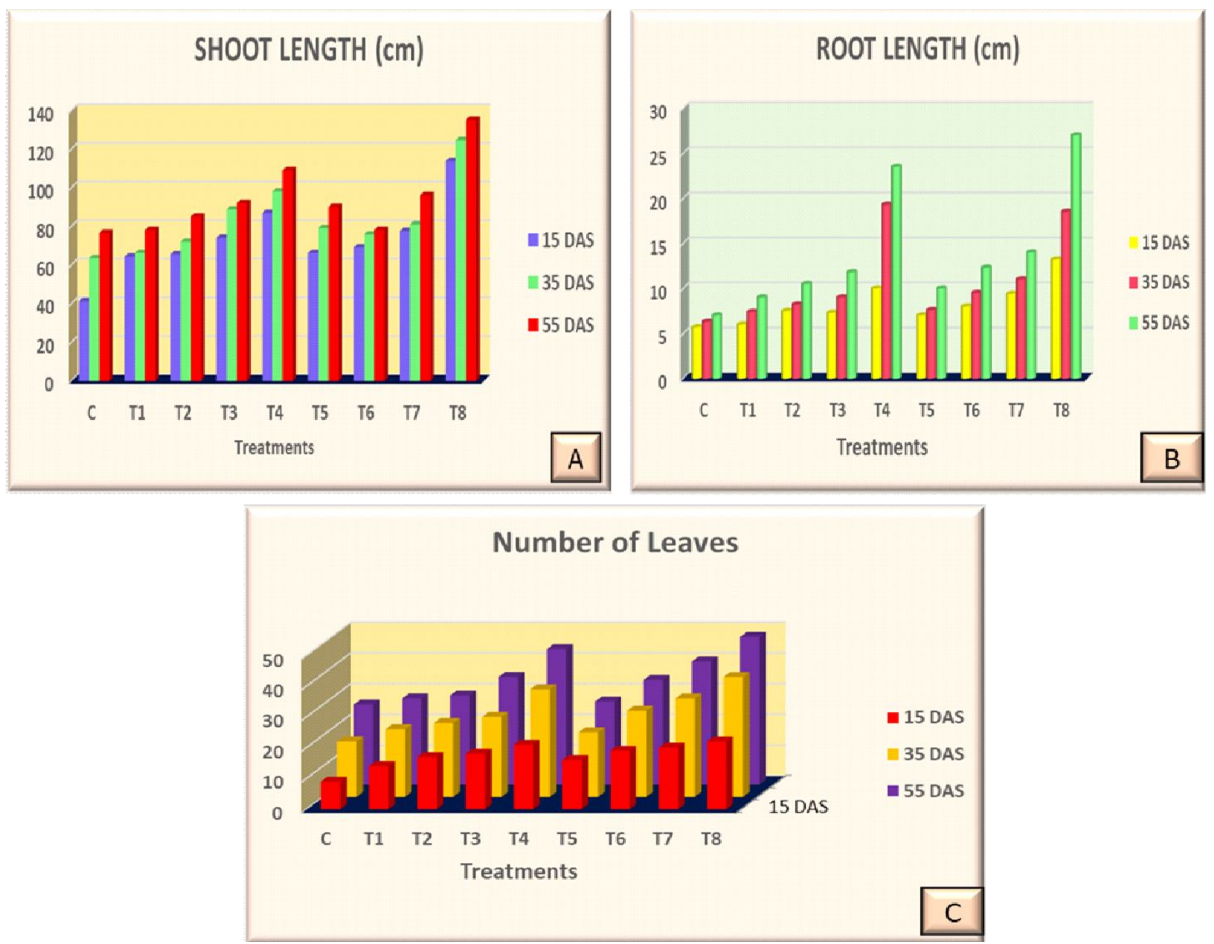

Fig 1: Effect of Composted Vegetable and fruit wastes on vegetative parameters of Lablab: A) Shoot length B) Root length C) Number of leaves.

C- Control, $\mathrm{T}_{1}$ - Vegetable Wastes + cow dung + Eudrilus eugeniae $(5 \mathrm{t} / \mathrm{ha}), \mathrm{T}_{2}$ - Vegetable Wastes + cow dung + Pleurotus eous + Eudrilus eugeniae $(5 \mathrm{t} / \mathrm{ha}), \mathrm{T}_{3}$ - Vegetable Wastes + cow dung + Trichoderma asperelloides + Eudrilus eugeniae $(5 \mathrm{t} / \mathrm{ha}), \mathrm{T}_{4}-\mathrm{Vegetable}$ Wastes + cow dung + P. eous $+T$. asperelloides + Eudrilus eugeniae $(5 \mathrm{t} / \mathrm{ha}), \mathrm{T}_{5}$ - Fruit Wastes + cow dung + Eudrilus eugeniae $(5 \mathrm{t} / \mathrm{ha})$, $\mathrm{T}_{6}$ - Fruit Wastes + cow dung + Pleurotus eous + Eudrilus eugeniae $(5 \mathrm{t} / \mathrm{ha}), \mathrm{T}_{7}$ - Fruit Wastes + cow dung + Trichoderma asperelloides + Eudrilus eugeniae $(5 \mathrm{t} / \mathrm{ha}), \mathrm{T}_{8}$ - Fruit Wastes + cow dung $+P$. eous $+T$. asperelloides + Eudrilus eugeniae $(5 \mathrm{t} / \mathrm{ha})$ 

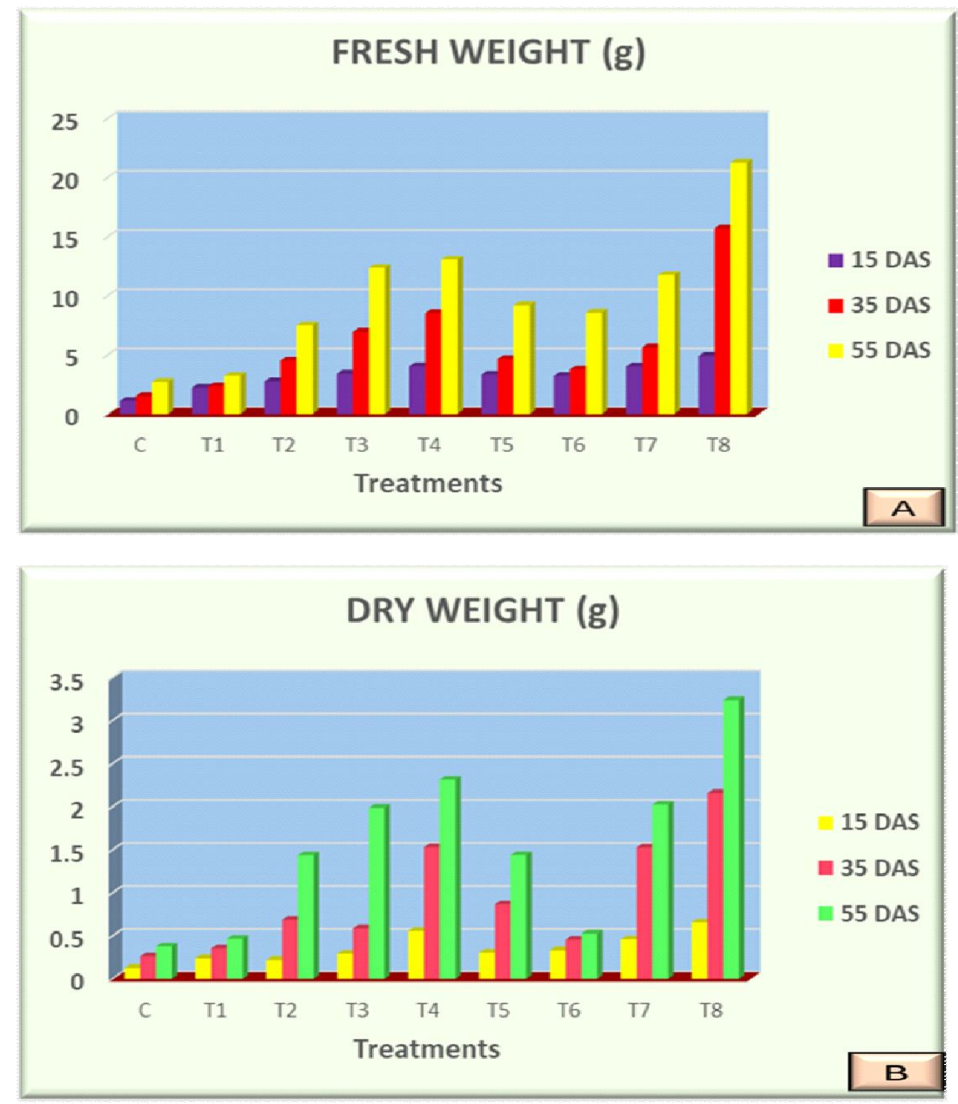

Fig 2: Effect of Composted Vegetable and fruit wastes on vegetative parameters of Lablab: A) Fresh weight (g) B) Dry weight (g). C- Control, $\mathrm{T}_{1}$ - Vegetable wastes + cow dung + Eudrilus eugeniae $(5 \mathrm{t} / \mathrm{ha}), \mathrm{T}_{2}$ - Vegetable wastes + cow dung + Pleurotus eous + Eudrilus eugeniae (5 t/ha), $\mathrm{T}_{3}$ - Vegetable wastes + cow dung + Trichoderma asperelloides + Eudrilus eugeniae $(5 \mathrm{t} / \mathrm{ha}), \mathrm{T}_{4}-$ Vegetable wastes + cow dung $+P$. eous $+T$. asperelloides + Eudrilus eugeniae $(5 \mathrm{t} / \mathrm{ha}), \mathrm{T}_{5}-$ Fruit Wastes + cow dung + Eudrilus eugeniae $(5 \mathrm{t} / \mathrm{ha}), \mathrm{T}_{6}-\mathrm{Fruit}$ Wastes + cow dung + Pleurotus eous + Eudrilus eugeniae (5 t/ha), $\mathrm{T}_{7}-$ Fruit Wastes + cow dung + Trichoderma asperelloides + Eudrilus eugeniae (5 t/ha), $\mathrm{T}_{8}$ - Fruit Wastes + cow dung + P. eous + T. asperelloides + Eudrilus eugeniae (5 t/ha).

Table 1: Effect of Composted Vegetable and fruit wastes on yield parameters of Lablab.

\begin{tabular}{lcccccc}
\hline Treatments & $\begin{array}{c}\text { Number of } \\
\text { pods/plants }\end{array}$ & $\begin{array}{c}\text { No. of } \\
\text { seeds/pod }\end{array}$ & $\begin{array}{c}\text { Pod length } \\
(\mathrm{cm})\end{array}$ & $\begin{array}{c}\text { Weight of } \\
\text { seed }(\mathrm{g})\end{array}$ & $\begin{array}{c}\text { Pod fresh } \\
\text { weight }(\mathrm{g})\end{array}$ & $\begin{array}{c}\text { Pod dry } \\
\text { weight(g) }\end{array}$ \\
\hline $\mathrm{C}$ & 16 & 3 & 9.00 & 1.771 & 4.408 & 0.530 \\
$\mathrm{~T}_{1}$ & 20 & 3 & 9.30 & 1.993 & 4.740 & 0.800 \\
$\mathrm{~T}_{2}$ & 23 & 4 & 10.40 & 2.172 & 6.220 & 0.886 \\
$\mathrm{~T}_{3}$ & 26 & 4 & 11.10 & 2.150 & 5.911 & 0.980 \\
$\mathrm{~T}_{4}$ & 35 & 5 & 12.30 & 2.813 & 5.003 & 1.122 \\
$\mathrm{~T}_{5}$ & 24 & 4 & 11.30 & 2.065 & 6.962 & 0.865 \\
$\mathrm{~T}_{6}$ & 32 & 4 & 11.60 & 2.089 & 6.233 & 1.070 \\
$\mathrm{~T}_{7}$ & 30 & 5 & 10.50 & 2.769 & 6.298 & 0.946 \\
$\mathrm{~T}_{8}$ & 40 & 6 & 13.00 & 4.060 & 0.1425 & 1.382 \\
SEd & 1.5870 & 0.9463 & 1.2511 & 0.1451 & 0.6722 & $(1.4123)$ \\
CD (P<0.05) & $(3.3342)$ & $(1.9882)$ & $(2.6284)$ & $(0.3049)$ & $(0.2309)$ \\
\hline
\end{tabular}

C- Control, $\mathrm{T}_{1}$ - Vegetable wastes + cow dung + Eudrilus eugeniae $(5 \mathrm{t} / \mathrm{ha}), \mathrm{T}_{2}$ - Vegetable Wastes + cow dung + Pleurotus eous + Eudrilus eugeniae $(5 \mathrm{t} / \mathrm{ha}), \mathrm{T}_{3}$ - Vegetable wastes + cow dung + Trichoderma asperelloides + Eudrilus eugeniae $(5 \mathrm{t} / \mathrm{ha}), \mathrm{T}_{4^{-}}$Vegetable Wastes + cow dung $+P$. eous $+T$. asperelloides + Eudrilus eugeniae $(5 \mathrm{t} / \mathrm{ha}), \mathrm{T}_{5}$ - Fruit wastes + cow dung + Eudrilus eugeniae $(5 \mathrm{t} / \mathrm{ha}), \mathrm{T}_{6}-\mathrm{Fruit}$ Wastes + cow dung + Pleurotus eous + Eudrilus eugeniae $(5 \mathrm{t} / \mathrm{ha}), \mathrm{T}_{7}-$ Fruit wastes + cow dung + Trichoderma asperelloides + Eudrilus eugeniae $(5 \mathrm{t} / \mathrm{ha}), \mathrm{T}_{8}$ - Fruit wastes + cow dung $+P$. eous $+T$. asperelloides + Eudrilus eugeniae $(5 \mathrm{t} / \mathrm{ha})$. 
(Vimera et al., 2012) and in pigeon pea where an increase in weight of pod, number of pods/plants $(243 \mathrm{~g}$ and $400 \mathrm{~g}$ ) were noted when poultry manure was used (Birajdar et al., 2018). Similar results were observed by Silpa and Vijayalakshmi (2021).

\section{CONCLUSION}

The vermicompost of vegetable and fruit wastes can be used as manure which is eco-friendly and sustainable to environment. The manure produced from the wastes are cost effective and eco-friendly. The study concluded that $T_{8}$ treatment showed the maximum increase in vegetative and yield parameters of Lablab. The present study is to propose the possibilities of using the municipal solid waste like vegetable and fruit wastes as manure to enhance the crop productivity which will help the farmers.

\section{ACKNOWLEDGEMENT}

We would like to thank Avinashilingam Institute for Home Science and Higher Education for Women and Ministry of Tribal Affairs for providing facilities and fund to carry out the study.

\section{REFERENCES}

Aalok Asha, A.K. Tripathi and Soni, P. (2008). Vermicomposting: A better option for organic solid waste management. Journal of Human Ecology. 24(1): 59-64.

Achsah, R.S. and Prabha, M.L. (2013). Potential of vermicompost produced from banana waste (Musa paradisiaca) on the growth parameters of Solanum lycopersicum. International Journal of Chemtech Research. 5: 2141-2153.

Afriyie, V. and Amoabeng, B.W. (2017). Effect of compost amendment on plant growth and yield of radish (Raphanus sativus L.). Journal of Experimental and Agriculture International. 15(2): 1-6.

Al- Sabbagh, T., Tareq Madouh, Craig, A.M. and Sugumaran, K. (2020). Influence of dead sheep compost material using aerobic technique on the growth of leafy vegetables in Kuwait under greenhouse conditions. Journal of Agriculture and Horticulture Research. 3(2): 31-37.

Birajdar, G.M., Gavali, M.T., Mane, S.R. and Bhale, U.N. (2018). Physico chemical parameters of organic compost and its impact on pigeon pea and Jowar crop plants productivity. International Journal Pharmacy and Biological Science. 13(2): 74 - 79.

Coulibaly, S.S., Kouassi, K.I., Koffi, K.K. and Zoro, B.I. (2019). Effect of compost from different animal manures on maize (Zea mays) growth. Journal of Experimental Biology and Agricultural Sciences. 7(2): 178-185.

Datar, M.T., Rao, M.N. and Reddy, S. (1997). Vermicomposting-A technological option for solid waste management. Journal of Solid Waste Technology and Management. 24(2): 89-93.

Dey, M., Mohilal, N. and Mongjam, S. (2019). Effect of compost and vermicompost prepared from different biodegradable wastes on the growth of King Chilli Capsicum Chinense. International Journal of Plant, Animal and Environmental Sciences. 9(2): 74-82.
Fuller, D.Q. (2003) African crops in prehistoric South Asia: A critical review. Food, fuel and fields: Progress in African archaeobotany. 239-271.

Joshi, D., Gediya, K.M., Patel, J.S., Birari, M.M., and Gupta, S. (2016). Effect of organic manures on growth and yield of summer cowpea [ Vigna unguiculata (L.) Walp] under middle Gujarat conditions. Agricultural Science Digest-A Research Journal. 36(2): 134-137.

Kumarimanimuthu, V. and Kalaimathi, P. (2020). Improving physiological and yield traits of groundnut (Arachis hypogaea L.) by using various sources of organic wastes and bio fertilizers, rhizobia. Indian Journal of Agricultural Research. 5: 1-5.

Mehdizadeh, M., Darbandi, E.I., Naseri-Rad, H. and Tobeh, A. (2013). Growth and yield of tomato (Lycopersicon esculentum Mill.) as influenced by different organic fertilizers. International Journal of Agronomy and Plant Production. 4(4): 734-738.

Nasar, J., Alam, A., Khan, M.Z., and Ahmed, B. (2019). Charcoal and compost application induced changes in growth and yield of Wheat (Triticum aestivum L.). Indian Journal of Agricultural Research. 53: 492-495.

Omidi, J., Abdolmohammadi, I.S., Hatamzadeh, A. and Khomami, A.M. (2017). Effect of the application of composted peanut shells on soil growing media on growth and nutrient elements of viola spp. International Journal of Farming and Allied Sciences. 6(5): 120-125.

Padmaja, C.K. and Jessy Paulose (2011). Efficacy of water hyacinth as green manure on test crop, green gram. International Journal of Plant Science. 6(1): 170-173.

Pavithra, R. and Lakshmi Prabha, M. (2014). Degradation of Leaf Litter by vermicomposting and its effect of growth on Cyamopsis tetragonoloba. International Journal of Chemtech Research. 6: 2985-2992.

Pinky Raihing and Vijayalakshmi, A. (2020). Biocomposting of Fruit Wastes into Manure and Its effects on the Growth, Chlorophyll content and Yield Parameters of Black Gram (Vigna Mungo L.). Proteus Journal. 11(10): 70-83.

Rashid, M.A., Shahadad Hussain, M., Motiur Rahaman, M. and Tauhidur Rahman, M. (2006). Indigenous vegetables in Bangladesh. In I International Conference on Indigenous Vegetables and Legumes. Prospectus for Fighting Poverty, Hunger and Malnutrition: Acta Horticulturae 752. (pp. 397-400).

Silpa, M. and Vijayalakshmi, A. (2021). Efficiency of biocomposted agroindustrial wastes and their response in the growth and Yield of Vigna unguiculata (L.) Walp. Agricultural Science Digest. DOI: 10.18805/ag.D-5321.

Sinha, J., Biswas, C.K., Ghosh, A. and Saha, A. (2010). Efficacy of Vermicompost against fertilizers on cicer and pisum and on population diversity of $\mathrm{N}_{2}$ fixing bacteria. Journal of Environmental Biology. 31: 287-292.

Vimera, K., Kanaujia, S.P., Singh, V.B. and Singh, P.K. (2012). Integrated nutrient management for quality production of king chilli (Capsicum chinense Jackquin) in an acid Alfisol. Journal of Indian Society and Soil Science. 60(1): 45-49.

Yagoub, S.O., Ali Ahmed, W.M. and Mariod, A.A. (2012). Effect of Urea, NPK and Compost on Growth and Yield of Soybean (Glycine max L.), in Semi-Arid Region of Sudan. ISRN Agronomy. Article ID- 678124: 1-6. 